\title{
Propofol attenuates hydrogen- peroxide-induced apoptosis in human umbilical vein endothelial cells via multiple signaling pathways
}

\author{
Cheng Lan Xie ${ }^{1,2}$, Yin Bing Pan ${ }^{1}$, Liu Qing Hu${ }^{1}$, and Yan Ning Qian ${ }^{1}$ \\ Department of Anesthesiology, ${ }^{1}$ the First Affiliated Hospital, Nanjing Medical University, Nanjing, ${ }^{2}$ Huaian Second \\ Hospital Affiliated to Xuzhou Medical College, Huaian, China
}

Background: Propofol has been reported to protect vascular endothelial cells against oxidative stress. In this study we investigated its effect on hydrogen peroxide $\left(\mathrm{H}_{2} \mathrm{O}_{2}\right)$-induced apoptosis of human umbilical vein endothelial cells (HUVECs) and examined the possible signaling pathways.

Methods: HUVECs were pretreated with propofol $(1,5,25$, and $50 \mu \mathrm{M})$ for $30 \mathrm{~min}$ and then co-incubated with $0.4 \mathrm{mM}$ $\mathrm{H}_{2} \mathrm{O}_{2}$ for $4 \mathrm{~h}$. Cell viability was assessed using a Cell Counting Kit-8. Cell apoptosis was analyzed using flow cytometry with annexin V/propidium iodide staining, and evaluated by quantifying caspase-3, Bax, and Bcl-2 expression levels. The expression levels of p38 mitogen activated protein kinase (MAPK), phosphorylated (p)-p38 MAPK, cJun-N-terminal kinases (JNK), phosphorylated (p)-JNK, Akt and phosphorylated Akt [(p)-Akt] (Ser473) were measured by western blotting.

Results: $\mathrm{H}_{2} \mathrm{O}_{2}$ treatment induced the activation of caspase-3, downregulated Bcl-2 expression, and up-regulated Bax expression, all of which were dose-dependently attenuated by propofol pretreatment. Furthermore, propofol significantly ameliorated $\mathrm{H}_{2} \mathrm{O}_{2}$-induced phosphorylation of p38 MAPK, JNK, and Akt in HUVECs.

Conclusions: Propofol can protect HUVECs against $\mathrm{H}_{2} \mathrm{O}_{2}$-induced apoptosis via a mechanism that may involve p38 MAPK, JNK, and Akt signaling pathways.

Key Words: Apoptosis, Human umbilical vein endothelial cell, Hydrogen peroxide, Propofol.

Corresponding author: Yan Ning Qian, M.D., Ph.D.

Department of Anesthesiology, the First Affiliated Hospital, Nanjing Medical University, 300 Guangzhou Road, Nanjing 210029, China

Tel: 86-25-83718836, Fax: 86-25-83718836

E-mail: yanning_qian@sina.com

Cheng Lan Xie and Yin Bing Pan contributed equally to this work.

Received: July 28, 2014.

Revised: 1st, September 15, 2014; 2nd, September 21, 2014.

Accepted: September 23, 2014.

Korean J Anesthesiol 2015 October 68(5): 488-495

http://dx.doi.org/10.4097/kjae.2015.68.5.488

\section{Introduction}

Vascular endothelial cells have important physiologic functions in maintaining cardiovascular stability. Many risk factors can cause endothelial cell dysfunction and result in apoptosis. The production of reactive oxygen species (ROS) is considered a crucial pathogenic factor in endothelial cell dysfunction and the development of cardiovascular diseases such as hypertension, atherosclerosis, and diabetic vasculopathy. Hydrogen peroxide $\left(\mathrm{H}_{2} \mathrm{O}_{2}\right)$, a major ROS, plays a crucial role in vascular dysfunction [1]. Many studies have revealed that $\mathrm{H}_{2} \mathrm{O}_{2}$ can damage and in-

(c) This is an open-access article distributed under the terms of the Creative Commons Attribution Non-Commercial License (http://creativecommons.org/ licenses/by-nc/4.0/), which permits unrestricted non-commercial use, distribution, and reproduction in any medium, provided the original work is properly cited. 
duce apoptosis in endothelial cells, the underlying mechanisms of which are associated with mitogen activated protein kinases (MAPKs) and Akt [2,3]. Among the MAPK members, cJun-Nterminal kinases (JNK) and p38 MAPK are preferentially activated in response to various stresses and pro-apoptotic signals in numerous cell types. The Akt pathway is commonly linked to survival pathways against multiple pro-apoptotic stimuli that induce its activation [4]. Thus, blockade of these pro-apoptotic pathways in endothelial cells is regarded as a potential therapeutic strategy to prevent or alleviate the progression of $\mathrm{H}_{2} \mathrm{O}_{2}$ induced cardiovascular diseases.

Propofol (2,6-diisopropylphenol) is an intravenous sedative/hypnotic agent widely used for anesthesia and sedation. Its structure is similar to that of the endogenous antioxidant a-tocopherol (Vitamin E) [5]. Propofol has anti-oxidant and anti-apoptotic effects $[2,6-8]$, but these vary among cell types and involve multiple mechanisms. Propofol differentially activates certain MAPKs depending on the cell type used and on the experimental conditions $[2,9,10]$. Additionally, the role of Akt in propofol-mediated anti-apoptotic processes remains controversial. Propofol has been shown to protect cardiac H9c2 cells against $\mathrm{H}_{2} \mathrm{O}_{2}$-induced injury by activating Akt [8]. However, Akt is not activated by $\mathrm{H}_{2} \mathrm{O}_{2}$ treatment, nor is it regulated by propofol pretreatment in human umbilical endothelial cells (HUVECs) [3]. Although the anti-apoptotic effect of propofol on vascular endothelial cells has been investigated extensively, the underlying mechanisms remain unclear.

This study aimed to examine the anti-apoptotic effects of propofol on HUVECs and evaluate the potential mechanisms. Our results suggested that the protective effect of propofol against $\mathrm{H}_{2} \mathrm{O}_{2}$-induced HUVEC dysfunction was most likely due to its anti-apoptosis action. Our study also demonstrated the involvement of the p38 MAPK, JNK and Akt pathways in this process.

\section{Materials and Methods}

\section{Reagents}

Propofol (purity $>97 \%$; Lot number: D126608) was obtained from Sigma Aldrich (St. Louis, USA). A Cell Counting Kit- 8 (CCK-8) was purchased from Dojindo laboratories (Kumamoto, Japan). A bicinchoninic acid (BCA) Protein Assay Kit was obtained from the Beyotime Institute of Biotechnology (Haimen, China). The Colorimetric CaspACE ${ }^{\mathrm{TM}}$ Assay System was purchased from Promega (Madison, WI, USA). Glyceraldehyde3-phosphate dehydrogenase (GAPDH) and rabbit polyclonal antibodies for Akt, phosphorylated (p)-Akt (Ser473), p38MAPK, phosphorylated (p)-p38MAPK, JNK, phosphorylated (p)-JNK, Bax, Bcl-2, and $\beta$-actin were obtained from Cell Signaling Technology (Beverly, MA, USA). Dimethyl sulfoxide (DMSO) was purchased from Biosharp (Hefei, China). All other chemicals and reagents used were commercially available and of standard biochemical quality.

\section{Cell culture and treatment}

HUVECs were obtained from human umbilical cord veins by digestion with $0.1 \%$ collagenase type II (Sigma) as previously described [11]. The cells were cultured in Dulbecco's modified Eagle's medium (DMEM, Hyclone, UT, USA) supplemented with heat-inactivated $15 \%$ fetal bovine serum, endothelial cell growth supplement, $100 \mathrm{U} / \mathrm{ml}$ penicillin, and $100 \mu \mathrm{g} / \mathrm{ml}$ streptomycin. The cells were then incubated at $37^{\circ} \mathrm{C}$ in $5 \% \mathrm{CO}_{2}$ and $95 \%$ air. HUVECs at passages 2-5 were used for the experiments. Blood vessels were labeled with anti-von Willebrand factor antibody [12]. After 1 week of culture, HUVECs were identified via immunofluorescence staining with an anti-von Willebrand factor antibody [13].

HUVECs were cultured and divided into eight groups depending on the treatment: Group $\mathrm{C} 1$ without any treatment was used as the control; cells in groups $\mathrm{C} 2, \mathrm{P}$, and $\mathrm{H}$ were incubated with $0.1 \%$ DMSO, $50 \mu \mathrm{M}$ propofol, and $400 \mu \mathrm{M} \mathrm{H}_{2} \mathrm{O}_{2}$, respectively, for $4 \mathrm{~h}$. In groups $\mathrm{P} 1+\mathrm{H}, \mathrm{P} 5+\mathrm{H}, \mathrm{P} 25+\mathrm{H}$ and $\mathrm{P} 50+\mathrm{H}$, cells were treated with $1,5,25$, and $50 \mu \mathrm{M}$ propofol, respectively, for $30 \mathrm{~min}$ and then incubated with $400 \mu \mathrm{M} \mathrm{H}_{2} \mathrm{O}_{2}$ for $4 \mathrm{~h}$. Propofol was prepared in DMSO and diluted with culture medium immediately before use.

\section{Cell viability assay}

Cell viability was tested using the CCK-8, according to the manufacturer's instructions [14]. Cells $\left(2 \times 10^{3} /\right.$ well $)$ were seeded in a 96-well flat-bottomed plate and treated with the indicated conditions at $37^{\circ} \mathrm{C}$. After $24 \mathrm{~h}, 10 \mu \mathrm{l}$ of WST- 8 dye were added into each well, the cells were incubated at $37^{\circ} \mathrm{C}$ for $1 \mathrm{~h}$, then the optical density at $450 \mathrm{~nm}$ was measured using a microplate absorbance reader Elx800 (Bio-Tek, Instruments, Inc., Winooski, VT, USA). Cells that stained positively with the CCK8 solution were considered viable and are presented as percentages compared with control cells.

\section{Annexin V-fluorescein isothiocyanate/propidium iodide (AV-FITC/PI) double-staining assay}

HUVECs treated with propofol and/or $\mathrm{H}_{2} \mathrm{O}_{2}$ were collected via trypsin digestion, washed with cold phosphate-buffered saline (PBS), and resuspended in Annexin $\mathrm{V}$ binding buffer. AVFITC [Becton Dickinson (BD) Biosciences, USA] at a final concentration of $1 \mu \mathrm{g} / \mathrm{ml}$ and $250 \mathrm{ng}$ of PI were added to a mixture containing $100 \mu \mathrm{l}$ each of cell resuspension and binding buffer 
(BD Biosciences, USA). The mixture was incubated in the dark for $15 \mathrm{~min}$ at room temperature. Cells were washed once with binding buffer and resuspended in $400 \mu$ of binding buffer prior to flow cytometric analysis using a BD FACScan Flow Cytometer (BD, Mountain View, USA).

\section{Caspase- 3 activity assay}

HUVECs were lysed and caspase-3 activity was measured in the cell lysate using the CaspACE ${ }^{\mathrm{TM}}$ Assay System. The colorimetric caspase-3-specific substrate, N-acetyl-Asp-Glu-Val-Aspp-nitroaniline that was provided within the Assay System was labeled with the chromophore p-nitroaniline (pNA). Free pNA produces a yellow color that is monitored by spectrophotometry at $405 \mathrm{~nm}$. The degree of yellow color produced upon cleavage was proportionate to the DEVDase (caspase-3) activity present in the sample.

\section{Western blotting}

Cells in a six-well plate were washed with PBS and lysed with lysis buffer containing phenylmethanesulfonyl fluoride (PMSF) at $4^{\circ} \mathrm{C}$ for $5 \mathrm{~min}$. The lysates were collected and centrifuged at $14,000 \mathrm{rpm}$ and $4^{\circ} \mathrm{C}$ for $15 \mathrm{~min}$, and the supernatant was collected for protein analysis using an Enhanced BCA Protein Assay Kit. The whole protein samples were boiled for $15 \min$ in $5 \times$ loading buffer and separated using 10\% sodium dodecyl sulfatepolyacrylamide gel electrophoresis (SDS-PAGE). Samples (50 $\mu \mathrm{g} /$ lane) were loaded on $10 \%$ SDS-PAGE, and proteins were transferred to polyvinylidene fluoride membranes at a current

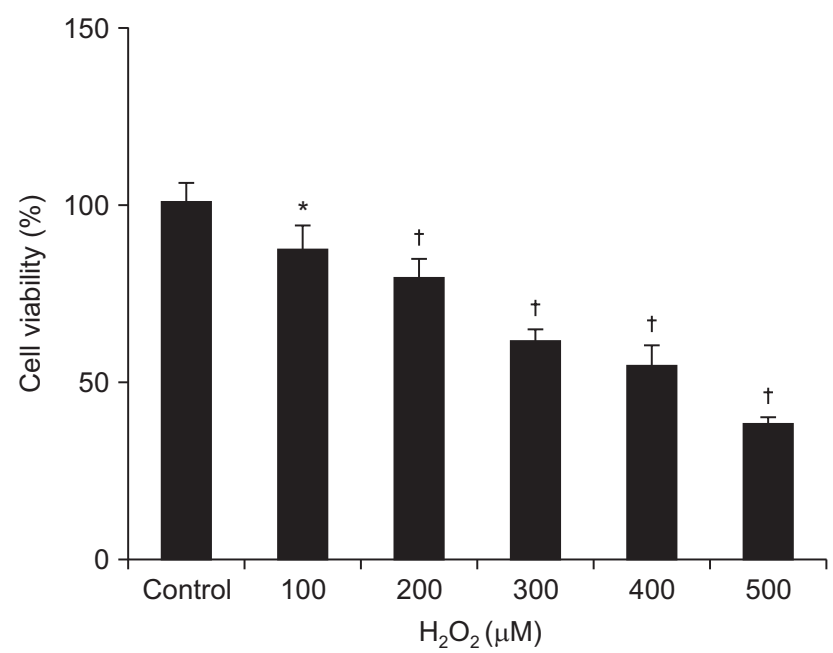

Fig. 1. $\mathrm{H}_{2} \mathrm{O}_{2}$ suppresses HUVEC viability in vitro dose-dependently. HUVECs were incubated with or without $\mathrm{H}_{2} \mathrm{O}_{2}$ for $4 \mathrm{~h}$. The results are expressed as means $\pm \mathrm{SD}(\mathrm{n}=5) .{ }^{*} \mathrm{P}<0.01,{ }^{\dagger} \mathrm{P}<0.001$ in comparison with controls. of $300 \mathrm{~mA}$ for $90 \mathrm{~min}$. The membranes were incubated in Trisbuffered saline containing $0.1 \%$ Tween-20 and 5\% dry milk, and then incubated overnight with anti-GAPDH, $\beta$-actin, Bax, Bcl2, caspase-3, p38MAPK, p-p38MAPK, JNK, p-JNK, Akt or pAkt (Ser473) antibodies. After $2 \mathrm{~h}$ of incubation with anti-rabbit horseradish peroxidase (HRP)-conjugated secondary antibodies, the protein bands were detected using an enhanced chemiluminescence (ECL) kit. The immune complexes were visualized via fluorography using an enhanced ECL system (Millipore, USA).

\section{Statistical analysis}

Data analysis was performed using GraphPad Prism 5.0 (GraphPad Software Inc., San Diego, CA). All experimental data were measured at least three times. The data were expressed as means $\pm \mathrm{SD}$, and results were analyzed by one-way ANOVA. A value of $\mathrm{P}<0.05$ was taken to indicate statistical significance.

\section{Results}

\section{Propofol pretreatment attenuated HUVEC cytotoxicity induced by $\mathrm{H}_{2} \mathrm{O}_{2}$}

Cell viability was measured using the CCK- 8 kit. After incubation with $100,200,300,400$ and $500 \mu \mathrm{M} \mathrm{H}_{2} \mathrm{O}_{2}$ for $4 \mathrm{~h}$, the viability of HUVECs was reduced significantly, in a dose-dependent manner (Fig. 1). When cells were treated with $400 \mu \mathrm{M}$ $\mathrm{H}_{2} \mathrm{O}_{2}$ for $4 \mathrm{~h}$, the cell viability was $\sim 50 \%$ of the control. Therefore, $400 \mu \mathrm{M} \mathrm{H}_{2} \mathrm{O}_{2}$ was used in subsequent experiments. Pro-

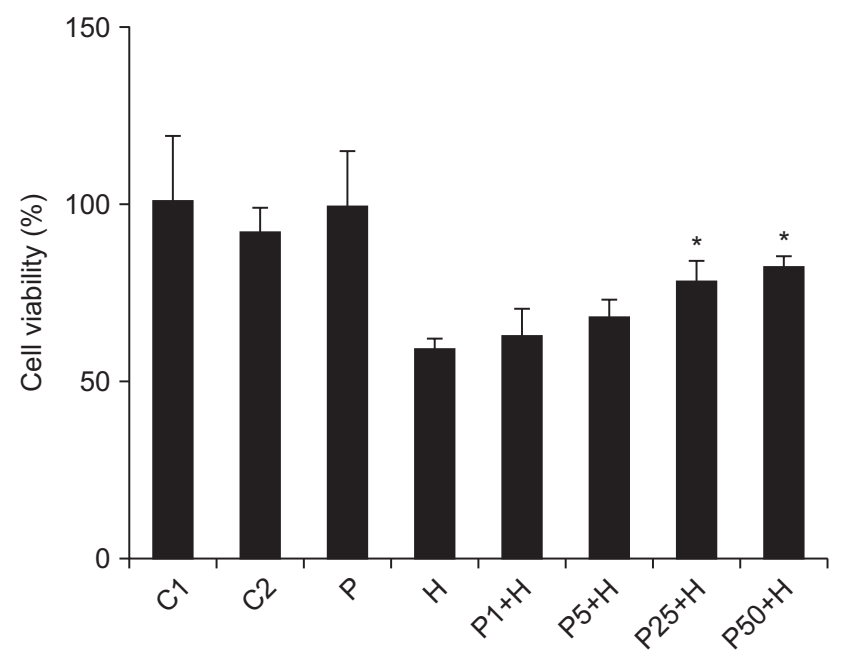

Fig. 2. Effect of propofol on $\mathrm{H}_{2} \mathrm{O}_{2}$-induced cytotoxicity. HUVECs were pretreated for $30 \mathrm{~min}$ with propofol $(0,1,5,25,50 \mu \mathrm{M})$ followed by $\mathrm{H}_{2} \mathrm{O}_{2}(400 \mu \mathrm{M})$ for $4 \mathrm{~h}$ (Group H, Group P1+H, Group P5+H, Group $\mathrm{P} 25+\mathrm{H}$ and Group P50+H, respectively). C1, C2 and P were the plain control, DMSO control, and propofol control groups, respectively. The results are expressed as means $\pm S D(n=5) . * P<0.05$ vs. H group. 
pofol alone did not affect cell viability as significantly as in the control group; however, pretreatment with propofol inhibited the $\mathrm{H}_{2} \mathrm{O}_{2}$-induced cytotoxicity in a dose-dependent manner (Fig. 2).

\section{Propofol reduced HUVEC apoptosis and necrosis induced by $\mathrm{H}_{2} \mathrm{O}_{2}$}

Using Annexin V/PI staining, we examined the protective role of propofol in $\mathrm{H}_{2} \mathrm{O}_{2}$-induced apoptosis. The apoptosis rate was the sum of early and late apoptosis events. As shown in Fig. 3, after $4 \mathrm{~h}$ of treatment with $400 \mu \mathrm{M} \mathrm{H}_{2} \mathrm{O}_{2}$, the proportion of apoptotic/necrotic cells was more than threefold that of the untreated control (Fig. 3B). Pretreatment with propofol significantly decreased $\mathrm{H}_{2} \mathrm{O}_{2}$-induced apoptosis. At 5, 25 and $50 \mu \mathrm{M}$, propofol markedly decreased the percentage of apoptotic cells following $\mathrm{H}_{2} \mathrm{O}_{2}$ treatment.

\section{Propofol decreased caspase-3 activity in HUVECs induced by $\mathrm{H}_{2} \mathrm{O}_{2}$}

$\mathrm{H}_{2} \mathrm{O}_{2}$ led to a significant increase in caspase- 3 activity. At 25 and $50 \mu \mathrm{M}$, propofol significantly reduced $\mathrm{H}_{2} \mathrm{O}_{2}$-induced caspase-3 activation (Fig. 4A).

A
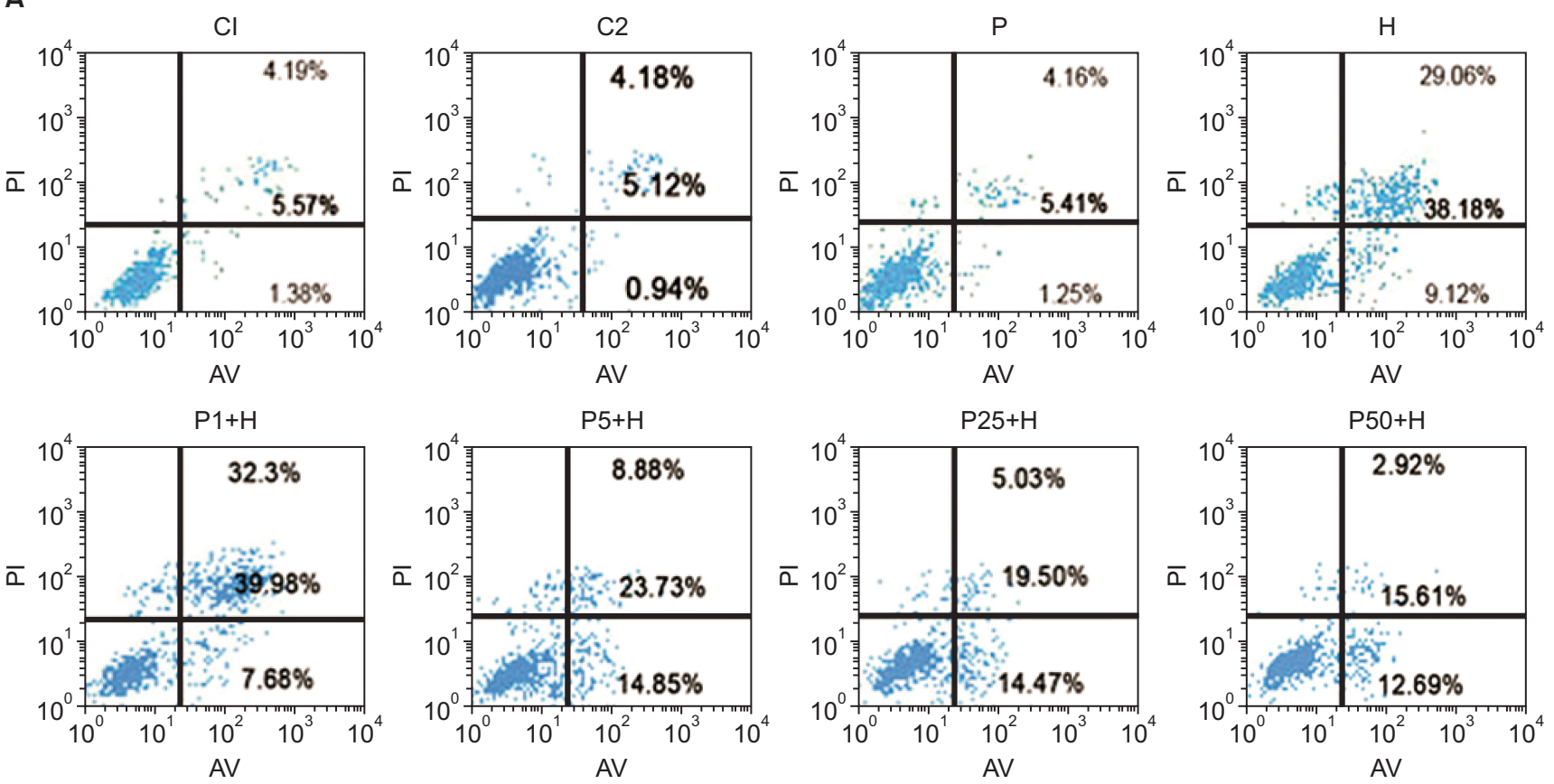

B

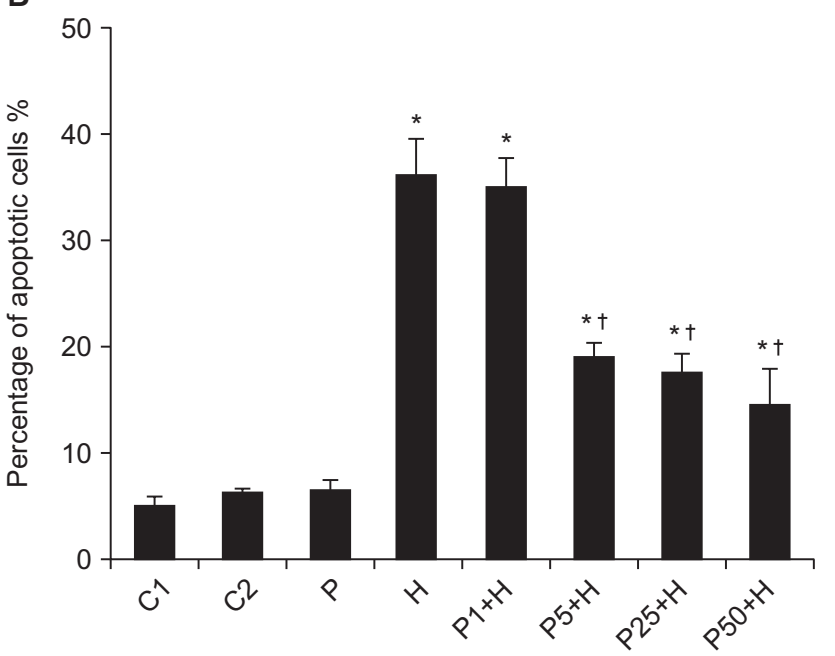

Fig. 3. Propofol reduced $\mathrm{H}_{2} \mathrm{O}_{2}$-induced apoptosis and necrosis in HUVECs. HUVECs were pretreated with propofol $(0,1,5,25,50 \mu \mathrm{M})$ for 30 min followed by $\mathrm{H}_{2} \mathrm{O}_{2}(400 \mu \mathrm{M})$ treatment for $4 \mathrm{~h}$ (Group $\mathrm{H}$, $\mathrm{P} 1+\mathrm{H}, \mathrm{P} 5+\mathrm{H}, \mathrm{P} 25+\mathrm{H}$ and $\mathrm{P} 50+\mathrm{H}$, respectively). $\mathrm{C} 1, \mathrm{C} 2$ and $\mathrm{P}$ were the plain control, DMSO control, and propofol control groups, respectively. Representative scatter plots of three independent experiments (A) and graphs (B) of three independent experiments. The results are expressed as means $\pm \mathrm{SD}(\mathrm{n}=5) .{ }^{*} \mathrm{P}<0.001$ vs. $\mathrm{C} 1$ group, ${ }^{\dagger} \mathrm{P}<0.001$ vs. H group. 
A

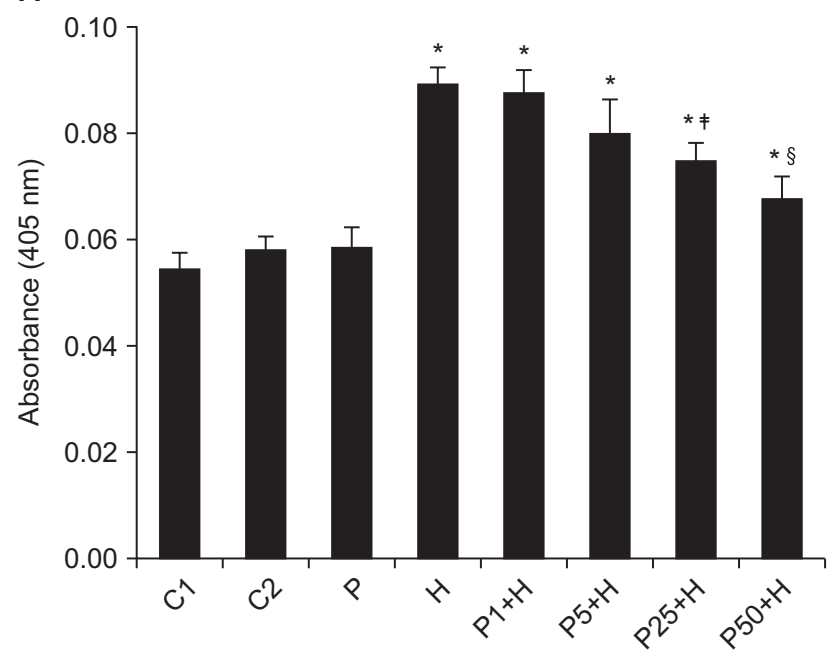

C

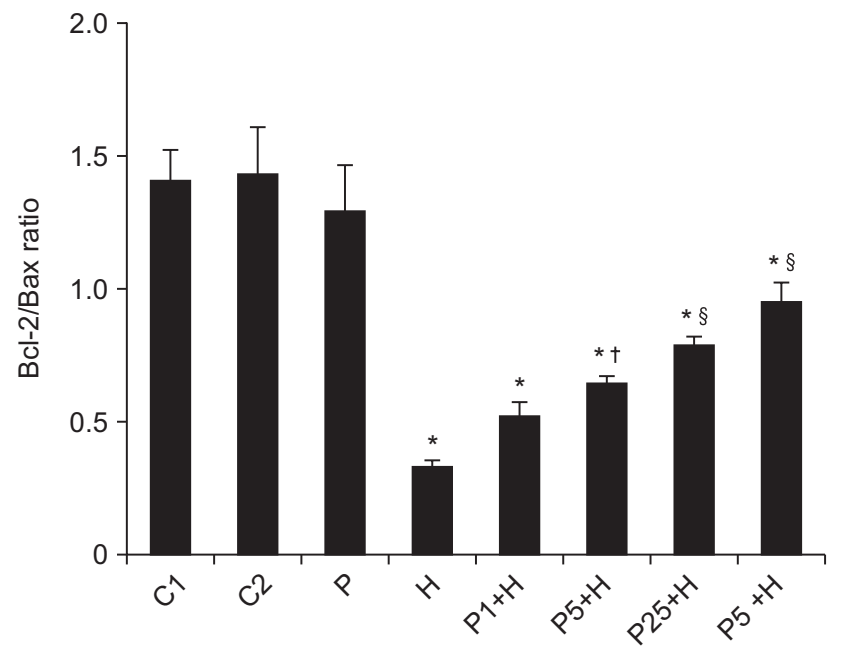

B

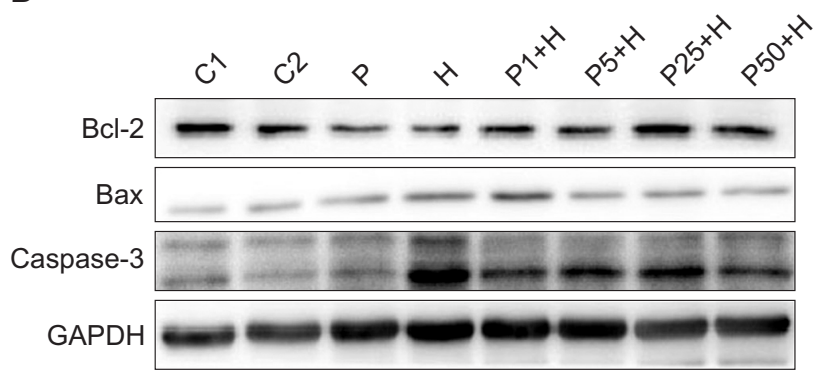

D

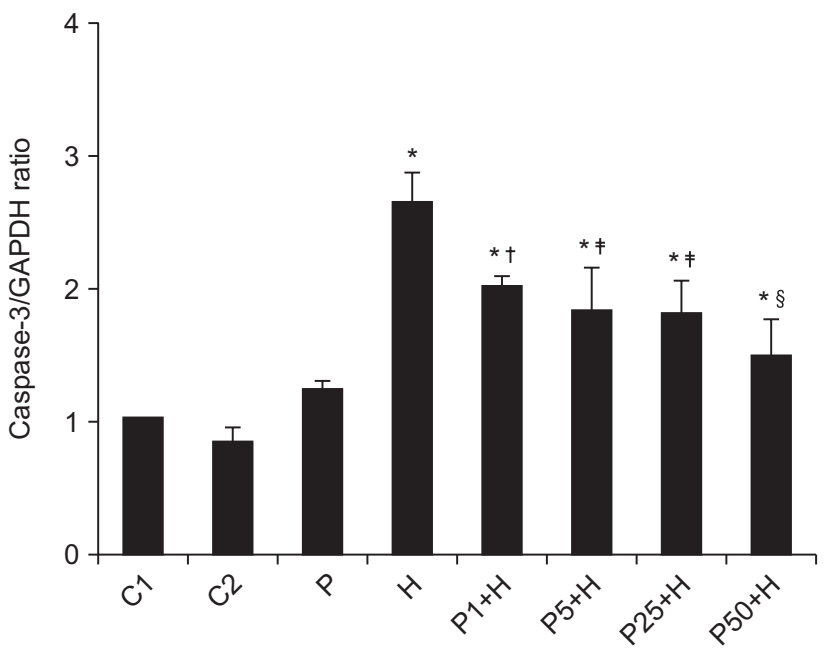

Fig. 4. Effects of propofol on $\mathrm{H}_{2} \mathrm{O}_{2}$-induced changes in caspase-3 activity and the protein levels of Bcl-2, Bax, and caspase-3. HUVECs were pretreated with propofol $(0,1,5,25,50 \mu \mathrm{M})$ for 30 min followed by $\mathrm{H}_{2} \mathrm{O}_{2}(400 \mu \mathrm{M})$ treatment for $4 \mathrm{~h}$ (Group $\mathrm{H}, \mathrm{P} 1+\mathrm{H}, \mathrm{P} 5+\mathrm{H}, \mathrm{P} 25+\mathrm{H}$ and $\mathrm{P} 50+\mathrm{H}$, respectively). $\mathrm{C} 1, \mathrm{C} 2$ and $\mathrm{P}$ were the plain control, DMSO control, and propofol control groups, respectively. (A) $\mathrm{H}_{2} \mathrm{O}_{2}$ treatment significantly induced caspase-3 activity, which was attenuated by pretreatment with propofol $(25,50 \mu \mathrm{M})$. (B) Representative western blot of Bcl-2, Bax, and caspase-3. (C) $\mathrm{H}_{2} \mathrm{O}_{2}$ treatment significantly decreased the $\mathrm{Bcl}-2 / \mathrm{Bax}$ ratio, which was increased by pretreatment with propofol $(5,25,50 \mu \mathrm{M})$ but not $\mathrm{DMSO}$. (D) $\mathrm{H}_{2} \mathrm{O}_{2}$ treatment significantly induced caspase- 3 expression, which was attenuated by pretreatment with propofol $(1,5,25,50 \mu \mathrm{M})$ but not DMSO. GAPDH was used as an internal control. The results are expressed as means $\pm \mathrm{SD}(\mathrm{n}=5) .{ }^{*} \mathrm{P}<0.05$ vs. C1 group, ${ }^{\dagger} \mathrm{P}<0.05,{ }^{\dagger} \mathrm{P}<0.01,{ }^{8} \mathrm{P}<0.001$ vs. $\mathrm{H}$ group.

\section{Effects of propofol on $\mathrm{BCl}-2$, Bax, and caspase-3 protein levels in $\mathrm{HUVECS}$ treated with $\mathrm{H}_{2} \mathrm{O}_{2}$}

Bax expression was increased and that of $\mathrm{Bcl}-2$ was decreased following $\mathrm{H}_{2} \mathrm{O}_{2}$ treatment. However, both changes were suppressed by pretreatment of cells with propofol (Figs. 4B and 4C).

The expression levels of caspase-3 in HUVECs were increased following $\mathrm{H}_{2} \mathrm{O}_{2}$ treatment. These increases were markedly reduced in the propofol-pretreated groups, in a dosedependent manner (Figs. 4B and 4D).

\section{Effects of propofol on p38 MAPK/JNK/Akt phosphorylation}

To determine the mechanisms of action of propofol, p38 MAPK, p-p38 MAPK, JNK p-JNK, Akt, and p-Akt (Ser473) were detected using western blotting. The results showed that $\mathrm{H}_{2} \mathrm{O}_{2}$ significantly activated the p38 MAPK, JNK and Akt signaling pathways. Pretreatment of cells with propofol attenuated this effect of $\mathrm{H}_{2} \mathrm{O}_{2}$ (Fig. 5). 
A

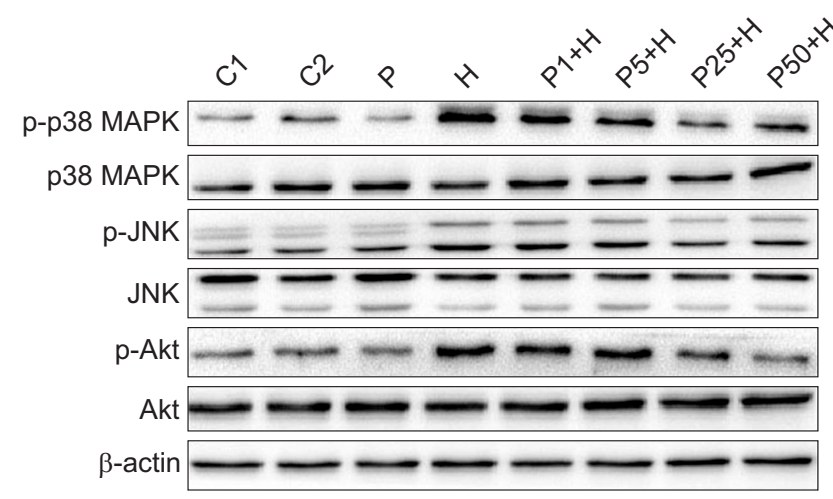

C

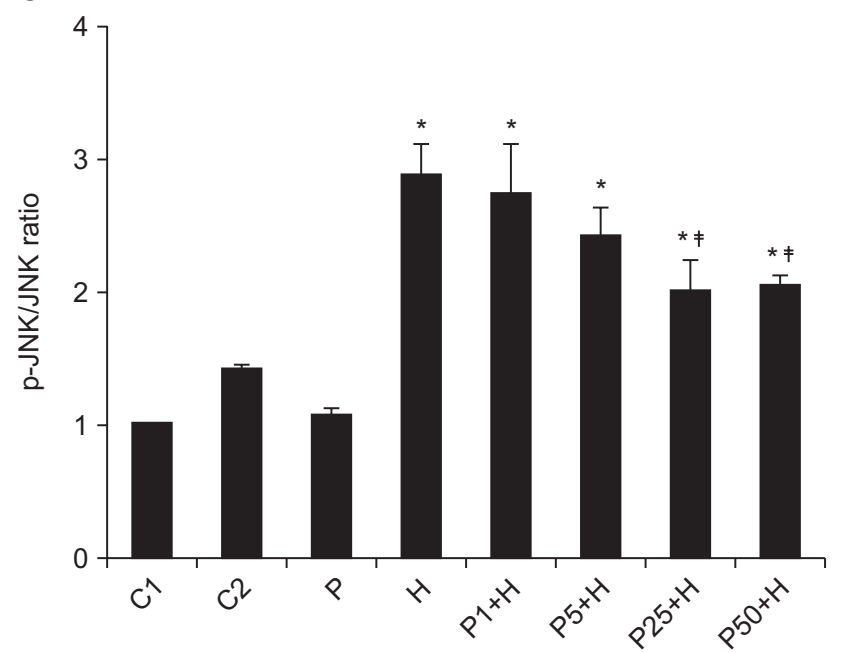

B

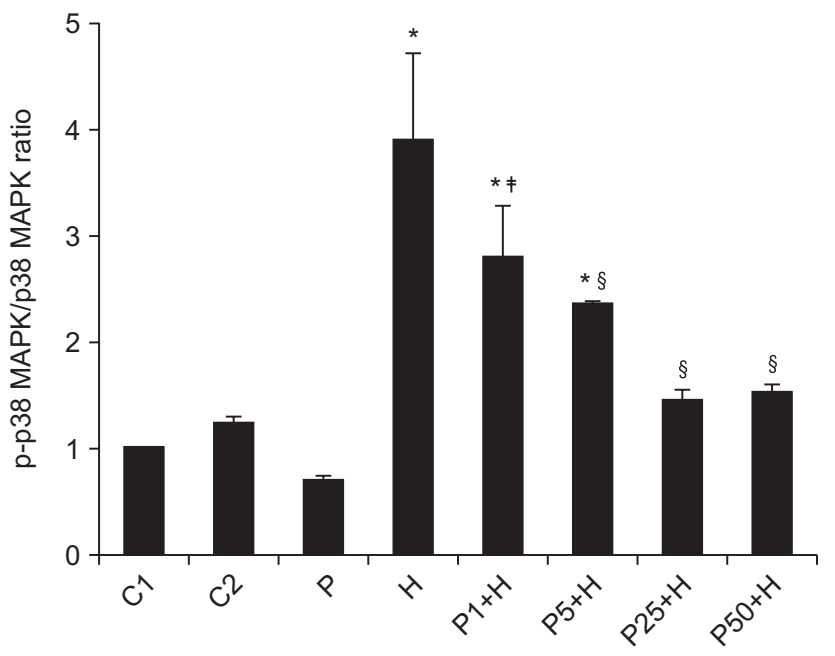

D

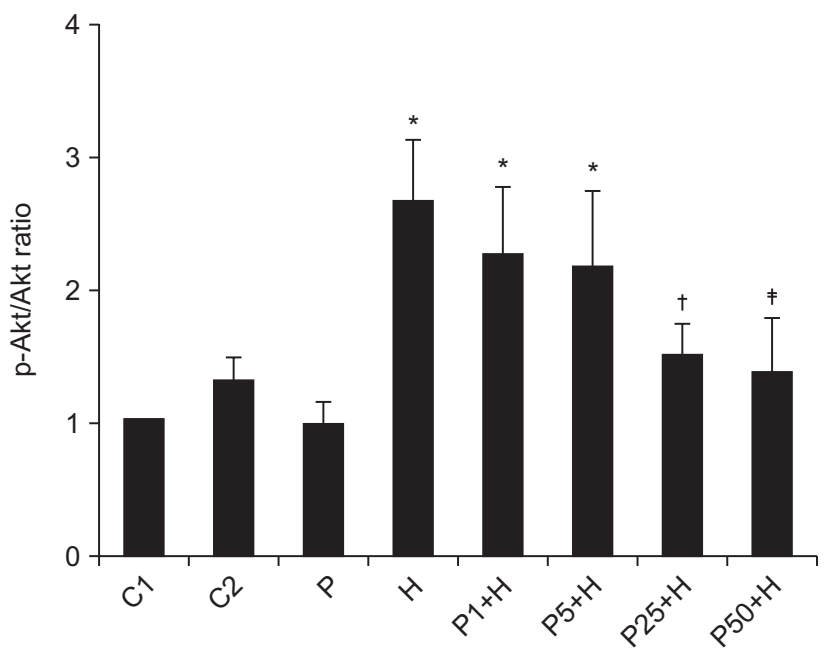

Fig. 5. Effects of propofol on the $\mathrm{H}_{2} \mathrm{O}_{2}$-induced phosphorylation of various signaling molecules. HUVECs were pretreated with propofol $(0,1,5,25$, $50 \mu \mathrm{M})$ for 30 min followed by $\mathrm{H}_{2} \mathrm{O}_{2}(400 \mu \mathrm{M})$ treatment for $4 \mathrm{~h}$ (Group $\mathrm{H}, \mathrm{P} 1+\mathrm{H}, \mathrm{P} 5+\mathrm{H}, \mathrm{P} 25+\mathrm{H}$ and $\mathrm{P} 50+\mathrm{H}$, respectively). C1, C2 and P were the plain control, DMSO control, and propofol control groups, respectively. (A) Representative western blot of phosphorylated p38 MAPK, JNK and Akt. Densitometric analysis of p-p38 MAPK (B), p-JNK (C) and p-Akt (D) bands normalized to $\beta$-actin. The results are expressed as means \pm SD $(n=5)$. $* \mathrm{P}<0.001$ vs. $\mathrm{C} 1$ group; ${ }^{\dagger} \mathrm{P}<0.05,{ }^{\dagger} \mathrm{P}<0.01,{ }^{\S} \mathrm{P}<0.001$ vs. $\mathrm{H}$ group.

\section{Discussion}

Propofol has been shown to have antioxidant and antiapoptotic effects [15]. In this study we showed that propofol protected HUVECs from cytotoxic reactive oxygen species in a dose-dependent manner. We found that the minimum effective concentration of propofol was $1 \mu \mathrm{M}$, which was equal to the initial concentration for sedation [16]. Since steady-plasma concentrations of propofol in a clinical setting are 10 to $50 \mu \mathrm{M}$ [17], we examined the effect of propofol at 1-50 $\mu \mathrm{M}$. In human leukocytes, the antioxidant effect of propofol is due in part to intralipid, the solvent used to deliver propofol to patients [18]. Accordingly, we chose dimethyl sulfoxide (DMSO) as the solvent to deliver propofol to the cells. However, DMSO has recently been proposed as a free radical scavenging agent [19]. To exclude the potential effect of DMSO, we included a DMSO control group in our experiments. The results showed that DMSO had no effect on $\mathrm{H}_{2} \mathrm{O}_{2}$-induced changes. Therefore, we concluded that propofol, rather than the solvent, affected the HUVECs.

The members of the Bcl-2 family of proteins serve as anti- or pro-apoptotic regulators that are associated with a wide variety of cellular activities $[4,20]$. Bcl-2 is an anti-apoptotic regulator and Bax is a pro-apoptotic regulator. The balance between antiand pro-apoptotic proteins partly determines the fate of the cell. On the other hand, caspases are a family of specific cysteine proteases whose activation is crucial to intracellular apoptosis. 
Among several identified caspases, caspase- 3 is a common target of several procaspases and caspases, and therefore, can act as an apoptotic marker induced by various stimuli [4]. It has been shown that $\mathrm{H}_{2} \mathrm{O}_{2}$-induced apoptosis in cardiomyocytes is ameliorated by propofol through up-regulation of $\mathrm{Bcl}-2$ and inhibition of caspase-3 [8]. In the present study, $\mathrm{H}_{2} \mathrm{O}_{2}$ resulted in a reduced Bcl-2/Bax ratio in HUVECs. At 1 to $50 \mu \mathrm{M}$, pretreatment with propofol increased expression of $\mathrm{Bcl}-2$ and decreased that of Bax in $\mathrm{H}_{2} \mathrm{O}_{2}$-treated HUVECs. Moreover, caspase- 3 activation induced by $\mathrm{H}_{2} \mathrm{O}_{2}$ was also decreased by propofol treatment in a dose-dependent manner. In agreement with the previously reported anti-apoptotic effects of propofol [8,21,22], this study showed that propofol significantly protects HUVECs against apoptosis due to oxidative stress.

Many studies on vascular endothelial cells have demonstrated protective effects of propofol against oxidative stress; however, the intracellular signaling pathways have remained unclear. Among the signaling pathways in endothelial cells, MAPKs and Akt are essential for death and survival, respectively [23]. It has been reported that p38 MAPK acts as a pro-apoptotic signal while Akt serves as an anti-apoptotic signal in oxidativestress-induced endothelial cells [24]. These effects are mediated by apoptosis-related factors from the Bcl-2 family of proteins [25]. The effects of the JNK pathway in apoptosis remain controversial, since both pro- and anti-apoptotic effects have been reported, depending on the apoptotic stimuli and cell type in question [4]. Moreover, JNK can also phosphorylate both proand anti-apoptotic members of the Bcl-2 family [26]. Therefore, in the present study, we used three well-established components of apoptotic signaling pathways, p38 MAPK, JNK, and Akt, as indicators to verify the protective effect of propofol against $\mathrm{H}_{2} \mathrm{O}_{2}$-induced HUVEC apoptosis. Our findings suggested that pretreatment with propofol inhibited the phosphorylation of p38 MAPK, JNK, and Akt in $\mathrm{H}_{2} \mathrm{O}_{2}$-induced HUVECs.

It has been reported that propofol inhibits the phosphorylation of p38 MAPK in $\mathrm{H}_{2} \mathrm{O}_{2}$-treated HUVECs [2]. Similarly, we found that p38 MAPK was significantly activated by oxidative stress in cultured HUVECs, and propofol at 1-50 $\mu \mathrm{M}$ markedly inhibited p38 MAPK phosphorylation in $\mathrm{H}_{2} \mathrm{O}_{2}$-treated HUVECs. JNK phosphorylation is activated in various cell types, including endothelial cells $[9,27]$; however, the effect of propofol on JNK in $\mathrm{H}_{2} \mathrm{O}_{2}$-treated HUVECs has, to our knowledge, not been investigated. Similar to the p38 MAPK results, JNK phosphorylation was induced by $\mathrm{H}_{2} \mathrm{O}_{2}$ and suppressed by pretreat- ment with $25-50 \mu \mathrm{M}$ propofol.

Akt is a critical regulator of cell survival that antagonizes mitochondria-directed apoptosis. Acute activation of Akt inhibits cell apoptosis induced by numerous stimuli, including $\mathrm{H}_{2} \mathrm{O}_{2}$ [8]. To determine whether Akt was the anti-apoptotic signaling pathway that mediates the protective role of propofol in HUVECs, we evaluated $\mathrm{H}_{2} \mathrm{O}_{2}$-induced phosphorylation and activation of Akt at Ser473. Treatment with $\mathrm{H}_{2} \mathrm{O}_{2}$ for $4 \mathrm{~h}$ markedly increased Akt phosphorylation, and pretreatment with 25-50 $\mu \mathrm{M}$ propofol for 30 min dramatically inhibited the $\mathrm{H}_{2} \mathrm{O}_{2}$ induced Akt phosphorylation in HUVECs. This finding was unexpected and seems to contradict the results of other studies $[3,8,28]$. Cell types, extracellular conditions, the altered cellular redox status and/or timing of Akt measurement may explain this discrepancy. Treatment of different cell types with various concentrations of $\mathrm{H}_{2} \mathrm{O}_{2}$ for different periods yields inconsistent results $[3,8]$. Additionally, the Akt pathway was fully activated at $\sim 10$ min after $\mathrm{H}_{2} \mathrm{O}_{2}$ treatment, and then declined gradually [8]. Regretfully, we did not measure Akt expression at $10 \mathrm{~min}$, but assayed it at $4 \mathrm{~h}$ after $\mathrm{H}_{2} \mathrm{O}_{2}$ treatment.

Several limitations to this study should be noted. Firstly, this study used only pretreatment with propofol for $30 \mathrm{~min}$ before co-incubation with $\mathrm{H}_{2} \mathrm{O}_{2}$. Post-treatment with low concentrations of propofol (e.g., $1-10 \mu \mathrm{M}$ ) is closer to the actual levels used for ICU long-term sedation in critically ill patients. Secondly, further studies using specific signal pathway inhibitors and measurement of the levels of proteins involved in many signaling pathways for various periods are required to elucidate the effects of propofol on endothelial cell apoptosis.

Propofol protected HUVCEs from $\mathrm{H}_{2} \mathrm{O}_{2}$-induced apoptosis in a dose-dependent manner. The mechanism may involve the p38 MAPK, JNK, and Akt signaling pathways. These findings suggest that propofol is a preemptive anesthetic in patients with cardiovascular disease such as hypertension, atherosclerosis, and diabetic vasculopathy.

\section{Acknowledgments}

We thank Medjaden Bioscience Limited for their assistance in editing this manuscript. This work was partly supported by National Natural Science Foundation of China (No. 81270429) and by Huaian Science and Technology Bureau Project (No. HAS05021).

\section{References}

1. Cai H. Hydrogen peroxide regulation of endothelial function: origins, mechanisms, and consequences. Cardiovasc Res 2005; 68: 26-36.

2. Chen J, Gu Y, Shao Z, Luo J, Tan Z. Propofol protects against hydrogen peroxide-induced oxidative stress and cell dysfunction in human 
umbilical vein endothelial cells. Mol Cell Biochem 2010; 339: 43-54.

3. Wang B, Luo T, Chen D, Ansley DM. Propofol reduces apoptosis and up-regulates endothelial nitric oxide synthase protein expression in hydrogen peroxide-stimulated human umbilical vein endothelial cells. Anesth Analg 2007; 105: 1027-33.

4. Ryter SW, Kim HP, Hoetzel A, Park JW, Nakahira K, Wang X, et al. Mechanisms of cell death in oxidative stress. Antioxid Redox Signal 2007; 9: 49-89.

5. Murphy PG, Myers DS, Davies MJ, Webster NR, Jones JG. The antioxidant potential of propofol (2,6-diisopropylphenol). Br J Anaesth 1992; 68: 613-8.

6. Ansley DM, Sun J, Visser WA, Dolman J, Godin DV, Garnett ME, et al. High dose propofol enhances red cell antioxidant capacity during CPB in humans. Can J Anaesth 1999; 46: 641-8.

7. Chen J, Chen W, Zhu M, Zhu Y, Yin H, Tan Z. Propofol attenuates angiotensin II-induced apoptosis in human coronary artery endothelial cells. Br J Anaesth 2011; 107: 525-32.

8. Wang B, Shravah J, Luo H, Raedschelders K, Chen DD, Ansley DM. Propofol protects against hydrogen peroxide-induced injury in cardiac H9c2 cells via Akt activation and Bcl-2 up-regulation. Biochem Biophys Res Commun 2009; 389: 105-11.

9. Gu J, Chi M, Sun X, Wang G, Li M, Liu L, et al. Propofol-induced protection of SH-SY5Y cells against hydrogen peroxide is associated with the HO-1 via the ERK pathway. Int J Med Sci 2013; 10: 599-606.

10. Liang C, Xue Z, Wang H, Li P. Propofol upregulates heme oxygenase-1 through activation of ERKs in human umbilical vein endothelial cells under oxidative stress conditions. J Neurosurg Anesthesiol 2011; 23: 229-35.

11. Jaffe EA, Grulich J, Weksler BB, Hampel G, Watanabe K. Correlation between thrombin-induced prostacyclin production and inositol trisphosphate and cytosolic free calcium levels in cultured human endothelial cells. J Biol Chem 1987; 262: 8557-65.

12. Uchihara T, Kondo H, Akiyama H, Ikeda K. Single-laser three-color immunolabeling of a histological section by laser scanning microscopy: application to senile plaque-related structures in post-mortem human brain tissue. J Histochem Cytochem 1995; 43: 103-6.

13. al-Mohanna F, Collison K, Parhar R, Kwaasi A, Meyer B, Saleh S, et al. Activation of naive xenogeneic but not allogeneic endothelial cells by human naive neutrophils: a potential occult barrier to xenotransplantation. Am J Pathol 1997; 151: 111-20.

14. Hou G, Xue L, Lu Z, Fan T, Tian F, Xue Y. An activated mTOR/p70S6K signaling pathway in esophageal squamous cell carcinoma cell lines and inhibition of the pathway by rapamycin and siRNA against mTOR. Cancer Lett 2007; 253: 236-48.

15. Marik PE. Propofol: an immunomodulating agent. Pharmacotherapy 2005; 25: S28-33.

16. McMurray TJ, Johnston JR, Milligan KR, Grant IS, Mackenzie SJ, Servin F, et al. Propofol sedation using Diprifusor target-controlled infusion in adult intensive care unit patients. Anaesthesia 2004; 59: 636-41.

17. McDermott BJ, McWilliams S, Smyth K, Kelso EJ, Spiers JP, Zhao Y, et al. Protection of cardiomyocyte function by propofol during simulated ischemia is associated with a direct action to reduce pro-oxidant activity. J Mol Cell Cardiol 2007; 42: 600-8.

18. Demiryürek AT, Cinel I, Kahraman S, Tecder-Unal M, Gögüş N, Aypar U, et al. Propofol and intralipid interact with reactive oxygen species: a chemiluminescence study. Br J Anaesth 1998; 80: 649-54.

19. Liang C, Xue Z, Cang J, Wang H, Li P. Dimethyl sulfoxide induces heme oxygenase-1 expression via JNKs and Nrf2 pathways in human umbilical vein endothelial cells. Mol Cell Biochem 2011; 355: 109-15.

20. Wang X. The expanding role of mitochondria in apoptosis. Genes Dev 2001; 15: 2922-33.

21. Chen RM, Tai YT, Chen TG, Lin TH, Chang HC, Chen TL, et al. Propofol protects against nitrosative stress-induced apoptotic insults to cerebrovascular endothelial cells via an intrinsic mitochondrial mechanism. Surgery 2013; 154: 58-68.

22. Ito T, Mishima Y, Ito A, Kameyama N, Harada H, Iwata O, et al. Propofol protects against anandamide-induced injury in human umbilical vein endothelial cells. Kurume Med J 2011; 58: 15-20.

23. Chavakis E, Dimmeler S. Regulation of endothelial cell survival and apoptosis during angiogenesis. Arterioscler Thromb Vasc Biol 2002; 22: $887-93$.

24. Irani K. Oxidant signaling in vascular cell growth, death, and survival : a review of the roles of reactive oxygen species in smooth muscle and endothelial cell mitogenic and apoptotic signaling. Circ Res 2000; 87: 179-83.

25. Morello F, Perino A, Hirsch E. Phosphoinositide 3-kinase signalling in the vascular system. Cardiovasc Res 2009; 82: 261-71.

26. Weston CR, Davis RJ. The JNK signal transduction pathway. Curr Opin Cell Biol 2007; 19: 142-9.

27. Zhang C, Yang L, Wang XB, Wang JS, Geng YD, Yang CS, et al. Calyxin Y induces hydrogen peroxide-dependent autophagy and apoptosis via JNK activation in human non-small cell lung cancer NCI-H460 cells. Cancer Lett 2013; 340: 51-62.

28. Jun JH, Cho JE, Shim YH, Shim JK, Kwak YL. Effects of propofol on the expression of matric metalloproteinases in rat cardiac fibroblasts after hypoxia and reoxygenation. Br J Anaesth 2011; 106: 650-8. 